\title{
DANA DESA DALAM PENGEMBANGAN EKONOMI LOKAL (Studi Desa Pangalloang Kecamatan Rilau Ale Kabupaten Bulukumba)
}

\author{
${ }^{1}$ Ilham Abu, ${ }^{2}$ Muhammad Aras \\ Universitas Mulawarman, Universitas Negeri Makassar \\ Email : Ilham.abu@fkip.unmul.ac.id / muhammadaras@unm.ac.id
}

\begin{abstract}
Abstrack
Village development has a very important and strategic role in the framework of National Development and Regional Development which involves most of the people who live in rural areas in order to improve their welfare, to increase community development in developing and advancing village development. Local Economic Development is an effort to free the community from everything that needs to be done to build prosperity.

The purpose of this research is to study the management and implementation of village funds as well as local economic development efforts in Bulukumba Regency where authority is given to village heads to support village development programs and community empowerment. This research is a descriptive qualitative research conducted in Pangalloang Village, Rilau Ale District, Bulukumba Regency. Data obtained by interview, observation and documentation.

The results showed that the management of village funds in local economic development in Bulukumba district was carried out well, with the collaboration carried out by the village government with the community in carrying out the development needed by the community. And also the village government cooperates with the private sector in building village roads and can also be denied by the village community.
\end{abstract}

\section{Abstrak}

Pembangunan desa mempunyai peranan yang sangat penting dan strategis dalam rangka Pembangunan Nasional dan Pembangunan Daerah yang menyentuh secara langsung kepentingan sebagian besar masyarakat yang bermukim di pedesaan dalam rangka upaya meningkatkan ke-sejahteraan mereka, untuk meningkatkan fasilitas masyarakat dalam mengembangkan dan memajukan produktivitas sebuah desa. Pengembangan Ekonomi Lokal adalah upaya untuk membebaskan masyarakat dari semua keterbatasan yang menghambat usahanya guna membangun kesejahteraannya.

Tujuan dari penelitian ini adalah untuk mengetahui pengelolaan dan pelaksanaan dana desa serta upaya dalam pengembangan ekonomi lokal di kabupaten Bulukumba yang mana kewenangannya diberikan kepada kepala desa untuk mendukung program pembangunan desa dan pemberdayaan masyarakat. Penelitian ini merupakan penelitian kualitatif deskriftif yang dilakukan di Desa Pangalloang, Kecamatan Rilau Ale, Kabupaten Bulukumba. Data didapatkan dengan cara wawancara, observasi dan dokumentasi.

Hasil penelitian menunjukkan bahwa pengelolaan dana desa dalam pengembangan ekonomi lokal di kabupaten bulukumba terlaksana dengan baik, dengan adanya kerjasama yang dilakukan oleh pemerintah desa dengan masyarak dalam melakuan pembangunan yang di butuhkan oleh masyarakt. Dan juga pemerintah desa malakukan kerjasama dalam oleh pihak swasta dalam pembagunan jalan desa dan juga dapat di bantuh oleh masyarakat desa.

Keywords: village funds and local economy

This is an open access article distributed under the Creative Commons Attribution License, which permits unrestricted use, distribution, and reproduction in any medium, provided the original work is properly cited. C2020 by author. 


\section{Introduction}

Salah satu tujuan pembangunan nasional adalah untuk dapat mewujudkan tujuan kemasyarakatan yaitu kesejahteraan dan keadilan dalam masyarakat. Dalam upaya untuk mencapai tujuan tersebut, pemerintah daerah dan masyarakatnya harus secara bersama-sama mengambil inisiatif pembangunan daerah. Oleh karena itu, pemerintah daerah beserta partisipasi masyarakatnya dan dengan menggunakan sumber daya-sumber daya yang ada harus mampu menaksir potensi sumber daya yang diperlukan untuk merancang dan membangun perekonomian daerah. Pencapaian tujuan pembangunan ekonomi daerah dibutuhkan kebijakan pembangunan yang didasarkan pada kekhasan daerah (endogenous development), dengan menggunakan potensi sumberdaya lokal. Identifikasi sektor ekonomi potensial menjadi kebutuhan bagi optimalisasi proses dan keberhasilan pembangunan ekonomi. Menanggapi permasalahan tersebut, strategi pemerintah untuk mengatasi ketimpangan pembangunan yaitu dengan melaksanakan pembangunan nasional yang menaruh perhatian besar terhadap pembangunan desa (Putra, 2013).

Pembangunan desa mempunyai peranan yang sangat penting dan strategis dalam rangka Pembangunan Nasional dan Pembangunan Daerah, karena di dalamnya terkandung unsur pemerataan pembangunan dan hasil-hasilnya serta menyentuh secara langsung kepentingan sebagian besar masyarakat yang bermukim di perdesaan dalam rangka upaya meningkatkan kesejahteraan mereka. Dalam pembangunan desa pemerintahan desa berkedudukan sebagai subsistem dari sistem penyelenggaraan pemerintahan di Indonesia, sehingga desa memiliki kewenangan, tugas dan kewajiban untuk mengatur dan mengurus kepentingan masyarakatnya sendiri. Dalam menyelengarakan kewenangan, tugas, dan kewajiban desa dalam penyelenggaraan pemerintahan maupun pembangunan maka dibutuhkan sumber pendapatan desa. Kebijakan dana desa sejalan dengan agenda otonomi daerah yang menempatkan desa sebagai basis desentralisasi (Kartika, 2012., Mahfud, 2009).

Dana Desa merupakan suplay dari pemerintah sebagai sarana penunjang dan juga impus untuk pembangunan dan pemeberdayaan masyarakat yang ada di sebuah desa, dimana bantuan tersebut digunakan sebagai fasilitas masyarakat dalam mengembangkan dan memajukan produktivitas sebuah desa. Artinya, anggaran pemerintah yang diberikan kepada desa terkait sepenuhnya adalah untuk fasilitas pembangunan dan pemberdayaan desa sebagai salah satu lembaga yang andil dalam format kepemerintahaan. Pemerintah daerah berupaya untuk meningkatkan kesejahteraan masyarakat dengan menggali dan mengembangkan potensi-potensi yang ada di wilayah tersebut melalui pengembangan ekonomi local (Susanti, et al. 2013).

Dari sisi masyarakat, Pengembangan Ekonomi Lokal diartikan sebagai upaya untuk membebaskan masyarakat dari semua keterbatasan yang menghambat usahanya guna membangun kesejahteraannya. Kesejahteraan tersebut dapat diartikan secara khusus sebagai jaminan keselamatan bagi adat istiadat dan agamanya, bagi usahanya, dan bagi harga dirinya sebagai manusia. Semua jaminan tersebut tidak dapat diperoleh dari luar sistem masyarakat karena tidak berkelanjutan, dan oleh karena itu harus diupayakan dari sistem masyarakat itu sendiri yang kerap kali disebut kemandirian. Dengan demikian, pembangunan ekonomi lokal merupakan upaya pemberdayaan masyarakat ekonomi dalam suatu wilayah dengan bertumpukan kepada kekuatan lokal, baik itu kekuatan nilai lokasi, sumber daya alam, sumber daya manusia, teknologi, kemampuan manajemen kelembagaan maupun aset pengalaman. Dalam ekonomi yang makin terbuka, ekonomi makin berorientasi pada pasar, peluang dari keterbukaan dan persaingan pasar belum tentu dapat dimanfaatkan oleh masyarakat yang kemampuan ekonominya lemah. Dalam keadaan ini harus dicegah terjadinya proses kesenjangan yang makin melebar, karena kesempatan yang muncul dari ekonomi yang terbuka hanya dapat dimanfaatkan oleh wilayah, sektor, dan golongan ekonomi yang lebih maju. Secara khusus perhatian harus diberikan dengan pemihakan dan pemberdayaan masyarakat melalui pembangunan ekonomi local (Hermawan, 2016., Harianto, 2016) .

Menurut Iqbal dan Anugrah (2009) Secara garis besar, langkah kegiatan Kebijakan pengembangan ekonomi lokal diawali dari proses sosialisasi, fasilitasi, hingga rekayasa kelembagaan. Tujuannya adalah untuk membangun kesadaran diantara para pemangku 
kepentingan, mobilisasi sumberdaya dalam wacana kemitraan, hingga pengembangan kelembagaan yang berdayaguna dalam jangka panjang. Sementara itu, target dan sasaran Kebijakan pengembangan ekonomi lokal harus sejalan dengan langkah dan tujuannya yaitu mulai dari timbulnya kesadaran para pemangku kepentingan terhadap eksistensi Kebijakan pengembangan ekonomi lokal, termobilisasinya sumberdaya sesuai dengan kebutuhan, hingga terlembaganya (institutionalized) KPEL. Tujuan pengembangan ekonomi lokal adalah menciptakan pertumbuhan ekonomi yang semakin tinggi dan berkelanjutan. Oleh karena itu seluruh pelaku pembangunan harus terlibat dalam proses perencanaan, pelaksanaan dan pengendalian kegiatan dalam kerangka pengembangan ekonomi lokal. Dalam hal ini peraturan Desa Pangaloang Kecamatan Rilau Ale Kabupaten Bulukumba tentang anggaran pendapatan dan belanja desa tahun aggaran 2016 Sebesar Rp. 996.401.683, dimana pengunaan dana untuk pembangunan dan pemberdayaan masyarakat di desa.

Pemberdayaan Masyarakat Desa adalah upaya mengembangkan kemandirian dan kesejahteraan masyarakat dengan meningkatkan pengetahuan, sikap, keterampilan, perilaku, kemampuan, kesadaran, serta memanfaatkan sumber daya melalui penetapan kebijakan, program, kegiatan, dan pendampingan yang sesuai dengan esensi masalah dan prioritas kebutuhan masyarakat Desa. Bentuk Pengembangan masyarakat yang diinginkan yaitu baik berupa pemberian bantuan alat maupun pelatihan yang diberikan kepada masyarakat yang memerlukannya (Atmojo, et al, 2017)

Namun yang terjadi kala ini pengembangan ekonomi pedesaan kurang berhasil. Hal ini muncul karana sarana dan prasarana pedesaan belum cukup memadai. Tidak hanya karena sebab itu perkonomian pedesaan kurang berkembang kurang pengetahuan/pendidikan, kurangnya semangat berkreasi, sampai minimnya lapangan pekerjaan adalah alasan yang paling sering muncul dan diperdengarkan untuk kurangnya berkembangan ekonomi pedesaan. Maka untuk membangun pertumbuhan ekonomi secara berkelanjutan yang berbasis Ekonomi pedesaan pemerintah harus membangun kembali jaringan penyuluhan dan pembinaan yang benar-benar berkelanjutan, terorganisir serta tepat sasaran, membangun jaringan pemasaran hasil produksi dengan memberdayakan koperasi secara mandiri dan professional, dan satu lagi yang tak kalah penting sekarang ini adalah banyaknya saluran irigasi sawah yang telah rusak. Pengembangan potensi desa bertujuan untuk mendorong terwujudnya kemandirian masyarakat melalui Pengembangan Potensi Unggulan dan Penguatan Kelembagaan serta Pemberdayaan Masyarakat (Soleh, 2017)

Mewujudkan tujuan itu, pemberdayaan dan pembangunan harus di tunjang dengan melaksanakan program organisasi, manajemen, keuangan, permodalan dan pengembangan usaha menjadi lebih baik dari tahun sebelumnya dan juga meninjau serta menata kembali langkah-langkah peningkatan tersebut sebagai jalan menuju visi masa depan yang lebih baik.

Penerapan teknologi dalam masyarakat pedesaan dalam meningkatkan hasil produksi di masa kini sangat dibutuhkan dan menjadi ketergantungan bagi masyakat pedesaan. Teknologi kemudian muncul menjadi salah satu solusi yang dianggap terbaik untuk menjawab dan menutupi minimnya lahan yang dimiliki oleh masyarakat pedesaan. Pembuatan bibit unggul, pestisida, pupuk, dan lain-lain.

Maka pemerintah mengeluarkan kebijakan yaitu Alokasi Dana Desa (ADD) untuk menunjang segala sektor di masyarakat. Alokasi Dana Desa merupakan salah satu bentuk hubungan keuangan antar tingkat pemerintahan yaitu hubungan keuangan antara pemerintahan kabupaten dengan pemerintahan desa. Untuk dapat merumuskan hubungan keuangan yang sesuai maka diperlukan pemahaman mengenai kewenangan yang dimiliki pemerintah desa.

Artinya, anggaran pemerintah yang diberikan kepada desa terkait sepenuhnya adalah untuk fasilitas pembangunan dan pemberdayaan desa sebagai salah satu lembaga yang andil dalam format kepemerintahaan. Dana tersebut harus digunakan dan di alokasikan sebagai mana mestinya sesuai dengan undang undang dan ketentuan yang berlaku yang telah ditetapkan pemerintah Indonesia. Sehingga dengan ADD tersebut mampu meningkatkan pembangunan desa, partisipasi masyarakat dalam memberdayakan dan menimplementasikan bantuan tersebut untuk kedepan. 
Indonesian Journal of Economics, Entrepreneurship and Innovation

Vol.1, No.1, Mei 2020

Available online: https:// https://journal.ilininstitute.com/IJoEEI

Ilham $\mathrm{Abu}^{1}$, Muhammad Aras ${ }^{2}$

Melihat fenomena seperti itu tampak belum ada kejelasan dalam pengaturan Alokasi Dana Desa dalam pengembangan ekonomi lokal. Oleh karena itu, penulis bermaksud melakukan suatu penelitian den gan judul: "Dana Desa Dalam Pengembangan Ekonomi Lokal Di Desa Pangaloang, Kecamatan Rilau Ale, Kabupaten Bulukumba".

\section{Method}

Penelitian ini mengunakan pendekataan kualitatif deskriftif, yakni dengan menggunakan dan memanfaatkan data dengan cara mengumpulkan, menjaring, dan mengolah data atau informasi untuk dipelajari dan dianalisis. Lokasi penelitian di Desa Pangaloang, Kecamatan Rilau Ale, Kabupaten Bulukumba. Adapun sumber data diperoleh dari Kepala Desa dan Masyarakat Desa serta Dokumen penggunaan dana desa anggaran 2016. Teknik pengumpulan data menggunakan observasi, wawancara dan dokumentasi. Kemudian data yang terkumpul di reduksi dan dianalisis untuk mendapatkan kesimpulan

\section{Results and Discussions}

Hasil

1. Faktor pendukung pengelolaan Dana Desa dalam pengembangan Ekonomi Lokal

Kegiatan Pengelolaan Keuangan Desa dapat dilaksanakan dengan baik tentunya harus didukung diantaranya oleh sumber daya manusia yang kompeten dan berkualitas serta sistem dan prosedur keuangan yang memadai. Oleh karenanya, pemerintah Desa harus memiliki struktur organisasi pengelolaan keuangan, uraian tugas, bagan alur, dan kriteria yang menjadi acuan dalam kegiatan pengelolaan keuangan Desa."

Dalam hal ini kekuasaan Pengelolaan Keuangan Desa dipegang oleh Kepala Desa. Namun demikian dalam pelaksanaannya, kekuasaan tersebut sebagian dikuasakan kepada perangkat Desa sehingga pelaksanaan pengelolaan keuangan dilaksanakan secara bersama-sama oleh Kepala Desa dan Pelaksana Teknis Pengelolaan Keuangan Desa (PTPKD). PTPKD terdiri dari Sekretaris Desa, Kepala Seksi dan Bendahara Desa.

Sebagaimana yang dikatakan oleh Bapak Asdar HC Manja selaku Kepala Desa Pangalloang mengatakan bahwa:

"Pemegang kekuasaan pengelolaan keuagan Desa kami mempunyai kewenangan, menetapkan kebijakan tentang pelaksanaan APBDesa, menetapkan PTPKD, menetapkan petugasa yang melakukan pemungutan penerimaan Desa, meyetujui pengeluaran atas kegiatan yang di tetapkan dalam APBDesa dan melakukan tindakan yang megakibatkan pengeluaran atas APBDesa."

Semua penerimaan dan pengeluaran Desa dalam rangka pelaksanaan kewenagan dilaksanakan melalui rekening kas Desa, rekening kas Desa adalah rekening tempat menyimpan uang pemerintah Desa yang menampung seluruh penerimaan Desa dan digunakan untuk membayar seluruh pegeluaran Desa yang pada bank yang ditetapkan. Penerimaan Desa adalah uang yang berasal dari seluruh pendapatan Desa yang masuk kedalam APBEDesa melalui rekening kas Desa, sedangkan pengeluaran Desa adalah uang yang dikeluarkan dari APBDesa melalui rekening kas Desa.

Berikut adalah tugas-tugas dari PTPKD yang ditetapkan oleh kepala Desa dalam membantu pengelolaan Dana Desa:

a. Sekretaris Desa

Sekretaris Desa di Desa Pangalloang adalah Bapak Burhan, SH. Sekretaris Desa selaku

Koordinator PTPKD membantu Kepala Desa dalam melaksanakan Pengelolaan Keuangan Desa. Setelah diwawancarai Bapak Burhan mengatakan bahwa:

"Saya selaku sekretaris Desa mendapatkan pelimpahan kewenangan dari Kepala Desa dalam melaksanakan Pengelolaan Keuangan Desa Pangalloang, dan bertanggungjawab kepada Kepala Desa, saya juga bekerja sama dengan kepala seksi dan bendahara" 
Tugas dan wewenang dari Sekretaris adalah:

1) Menyusun dan melaksanakan kebijakan pengelolaan APBDesa;

2) Menyusun rancangan peraturan Desa mengenai APBDesa, perubahan APB Desa dan pertanggungjawaban pelaksanaan APB Desa;

3) Melakukan pengendalian terhadap pelaksanaan kegiatan yang telah ditetapkan dalam APB Desa;

4) Menyusun pelaporan dan pertanggungjawaban pelaksanaan APB Desa;

5) Melakukan verifikasi terhadap Rencana Anggaran Belanja (RAB), bukti-bukti penerimaan dan pengeluaran APB Desa (SPP).

b. Kepala Seksi

Salah satu kepala seksi yang ditetapkan dan ditunjuk oleh Kepala Desa dalam bidang pembangunan Desa yaitu Bapak Asri, setelah diwawancarai mengatakan bahwa:

"Saya ditunjuk oleh bapak Kepala Desa untuk mempertanggung jawabkan urusan pembangunan jalan. Tugas saya yaitu melaksanakan pembangunan jalan dibantu oleh masyarakat setempat dan melaporkan seluruh perkembangan pembangunan jalan kepada Kepala Desa dan juga melaporkan seluruh pengeluaran selama pembangunan."

Kepala seksi merupakan salah satu unsur dari PTPKD yang bertindak sebagai pelaksana kegiatan sesuai dengan bidangnya. Sesuai pasal 64 PP Nomor 43 Tahun 2014 dinyatakan bahwa Desa paling banyak terdiri dari 3 (tiga) seksi. Kepala Seksi mempunyai tugas:

1) Menyusun RAB kegiatan yang menjadi tanggungjawabnya;

2) Melaksanakan kegiatan dan/atau bersama Lembaga Kemasyarakatan Desa yang telah ditetapkan di dalam APB Desa;

3) Melakukan tindakan pengeluaran yang menyebabkan atas beban anggaran belanja kegiatan;

4) Mengendalikan pelaksanaan dengan melakukan pencatatan dalam Buku Pembantu Kas Kegiatan;

5) Melaporkan perkembangan pelaksanaan kegiatan kepada Kepala Desa;

6) Mengajukan SPP dan melengkapinya dengan bukti-bukti pendukung atas beban pengeluaran pelaksanaan kegiatan.

c. Bendahara Desa

Bendahara Desa merupakan salah satu unsur dari PTPKD yang dijabat oleh kepala/staf urusan keuangan dan memiliki tugas untuk membantu Sekretaris Desa. Bendahara Desa di Desa Pangalloang adalah Bapak Yusuf Salri setelah diwawancarai Bapak Yusuf Salri mengatakan bahwa:

"Tugas saya dalam membantu sekretaris Desa dalam mengelola keuangan Desa yang yaitu penerimaan pendapatan Desa dan pengeluaran/pembiayaan dalam rangka pelaksanaan APB Desa. Untuk penatausahaan saya lakukan dengan menggunakan Buku Kas Umum, Buku Kas Pembantu Pajak, dan Buku Bank."

Penatausahaan yang dilakukan antara lain meliputi yaitu:

1) Menerima, menyimpan, menyetorkan/membayar, memungut dan menyetorkan $\mathrm{PPH}$ dan pajak lainnya;

2) Melakukan pencatatan setiap penerimaan dan pengeluaran serta melakukan tutup buku setiap akhir bulan secara tertib;

3) Mempertanggungjawabkan uang melalui laporan pertanggungjawaban.

\section{Faktor-faktor yang mendukung pelaksanaan program Dana Desa dalam pengembangan ekonomi lokal}

Faktor pendukung pelaksanaan program Dana Desa yaitu adanya kebijakan dari pemerintah Desa dan keterlibatan masyarakat. Untuk lebih jelasnya peran dan pengelolaannya dapat diuraikan sebagai berikut:

a. Kebijakan dari pemerintah Desa

1) Arah kebijakan pembangunan Desa

Menurut hasil wawancara dengan Bapak Asdar HC Manja mengatakan bahwa: 
"Arah kebijakan pembagunan Desa pangalloang yang dituangkan dalam RPJMDes tahun 2013-2017 merupakan bagian yang tak terpisahkan dengan visi dan misi Desa."

Menurutnya arah kebijakan adalah pedoman untuk menjabarkan rumusan misi Desa agar lebih terarah dalam mencapai tujuan dan sarana dalam setiap tahapan pembagunan selama 6 tahun secara operasional, penyusunan arah kebijakan pembaguanan Desa pangalloang tahun 2013-2017 didasarkan pada tujuan dan sasaran yang ingin dicapai, dimana sasaran dan tujuan merupakan langkah operasional dari setiap misi Desa.

Arah kebijakan pembagunan Desa pangalloang berdasarkan misi Desa sebagai berikut:

a) Peningkatan kualitas sumber daya masyarakat dengan moral akhlak yang tinggi.

b) Meningkatkan kelembagaan serta peran masyarakat

c) Menumbuhkan dan mengaktifkan kelompok tani dalam upaya peningkatan produksi pangan

d) Mengupayakan tersedianyan sarana produksi yang dibutuhkan masyarakat.

2) Potensi dan Masalah

Potensi dan masalah merupakan hal yang harus nampak dalam rumusan rencana pembangunan Desa pangalloang sebab potensi yang menggambarkan potensi Desa sedangkan masalah merupakan permasalahan-pemasalahan yang harus menjadi target penyelesaian atau program pembagunan.

"Menurut kepala Desa, Potensi ini masuk dalam beberapa bagian yaitu potensi umum dan potensi khusus, potensi umum merupakan potensi Desa yang ada diDesa yang kepemilikannya secara khusus, seperti persawahan, perkebunan, dan usaha-usaha warga, potensi Desa menjadi acuan dan perumusan pelaksanaan pembagunan potensi-potensi yang cukup menonjol di Desa menjadi acuan juga dalam rumusan visi dan misi Desa, sehingga program pembagunan harus mengarah kesana."

\section{3) Program Pembangunan Desa}

Dalam penyusunan pembangunan Desa dimana hasil penjaringan masalah dan potensi yang telah dilakukan disusun kemudian dikumpulkan dan di kelompokkan, lalu dikaji dan dianalisis dalam lokakarya 1 Desa Pangalloang. Lokakarya ini dilakukan pada hari Senin tanggal 11 Januari Tahun 2013 di Kantor Desa Pangalloang. Proses pengkajian ini dilakukan dengan tahapan sebagai berikut:

a) Penentuan peringkat masalah

Penentuan peringkat masalah bertujuan untuk mengetahui prioritas-prioritas permasalahan yang harus segera dipecahkan. Teknik yang digunakan dalam penentuan ini adalah pembobotan

b) Pengkajian peringkat masalah

Pengkajian pemecahan masalah dilakukan untuk menemukan berbagai alternative tindakan pemecahan masalah dengan memperhatikan akar penyebab masalah dan potensi yang ada.

c) Penentuan peringkat tindakan

Untuk waktu pelaksanaan disepakati, kegiatan pembangunan akan berlangsung selama lima tahun yakni dari tahun 2013 hingga 2017, sedangkan untuk sumber pembiayaannya berasal dari pemerintah, masyarakat, dan pihak ketiga. Pembiayaan pemerintah bersumber dari anggaran pendapatan dan belanja daerah (APBD), Alokasi Dana Desa (ADD) dan Bantuan Dana Desa (BDD).

1. Program dalam bidang sarana dan prasarana
a) Pembagunan jembatan
b) Pembagunan jalanan
c) Sarana irigasi
d) Sarana pendidikan dan kesehatan
e) Pembangunan saluran drainase

2. Program peningkatan pemberdayaan masyarakat peDesaan, dengan kegiatan

a) Pemberdayaan lembaga dan organisasi masyarakat peDesaaan

b) Penyelanggaraan pendidikan dan pelatihan tenaga tekhnis 
c) Program pengembangan lembaga ekonomi peDesaan dengan kegiatan

d) Pelatihan kewirausahaan

e) Pelatiahan keterampilan manajemen BKD dan UKD

f) Pelatiahan keterampilan usaha industry

g) Kerajinan fasilitas permodalan

3. Program peningkatan partisipasi masyarakata dalam membagun Desa dengan kegiatan

a) Pembinaan kelompok pengajian untuk pembinaan moral warga

b) Pembinaan kelompok belajara masyarakat untuk keaksaraan fungsional

c) Pelaksanaan musyawara pembagunan Desa

d) Pemberian stimulant pembagunan Desa

e) Monitoring evaluasi dan pelaporan

4. Program peningkatan kapasitas aparatur pemerintah Desa dengan kegiatan

a) Pelatihan aparatur pemerintah Desa dalam bidang pemenfaatan teknologi informasi untuk manajemen data kependudukan dan pemerintahan

b) Pelatihan aparutur pemerintah Desa dalam bidang pengelolaan keuangan Desa bahwa:

Menurut Bapak Yusuf Salri selaku bendahara Desa setelah siwawancarai mengataakan

"Banyak program yang sudah di usulkan oleh masyarakat. Namun pemerintah Desa belum dapat merealisasikan semua, yang menjadi fokus utama dan yang menjadi kepentingan masyarakat adalah Pembangunan Jalan dan jembatan, Pembangunan drainase. Anggaran yang dikeluarkan keluarkanpun sesuai dengan kebutuhan pelaksanaan program." bahwa:

Dibenarkan oleh Kepala Desa Pangalloang Bapak Asdar HC Manja yang mengatakan

"Pemerintah Desa dan masyarakat tidak memprogramkan pengembangan ekonomi lokal melihat dengan banyaknya bantuan-bantuan yang diberikan oleh pihak Dinas Pertanian yaitu berupa bibit cengkeh, bibit merica, bibit padi dan bahkan mobil traktor. Dan juga

Dinas Sosial yaitu memberikan bantuan kepada masyarakat yang memiliki usaha tersendiri berupa mesin jahit, alat pertukangan, alat perbenkelan."

Dengan adanya bantuan dari pemerintah Desa yang bekerja sama dengan dinas Pertanian dan Dinas Soaial mereka merasa sangat senang karena banyak yang memperhatikan. Menurut Ibu Nanna salah satu masyarakat yang mendapatkan bantuan dari Dinas Sosial berupa mesin jahit mengatakan bahwa:

"Saya sudah mendapatkan bantuan berupa mesin jahit dan saya merasa dengan adanya bantuan tersebut sangat membantu karena itu bisa memperlancar usaha saya dan orderan yang masuk bisa dia selesaikan dengan cepat dengan dibantu oleh keluarga sehingga konsumen tidak banyak mengeluh lagi karena barangnya cepat selesai."

\section{b. Peran Serta Masyarakat}

Dalam pengembangan ekonomi lokal, peran serta masyarakat merupakan suatu hal yang penting. Karena tanpa adanya peran dari masyarakat tentu saja pengembangan ekonomi lokal tidak akan dapat berjalan dengan baik. Oleh karena itu perlu adanya pemberdayaan masyarakat yang dilakukan oleh pemerintah untuk meningkatkan kemampuan dan kemandirian dari masyarakat itu sendiri. Pemberdayaan masyarakat merupakan suatu proses di mana masyarakat, khususnya mereka yang kurang memiliki akses ke sumber daya pembangunan, didorong untuk meningkatkan kemandiriannya di dalam mengembangkan kehidupan mereka.

Kepala Desa Pangalloang yaitu Bapak Asdar HC Manja setelah diwawancarai mengatakan bahwa:

"Tanpa adanya peran masyarakat maka pengembangan ekonomi lokal tidak akan berjalan dengan baik. Perlunya pemberdayaan masyarakat yang dilakukan oleh pemerintah untuk meningkatkan kemampuan dan kemandirian dari masyarakat. Dimana anggota masyarakat bekerja sama dengan kelompok formal maupun informal untuk berbagi pengetahuan dan pengalaman serta berusaha mencapai tujuan bersama. Jadi pemberdayaan masyarakat merupakan suatu proses." 
Kondisi masyarakat Desa Pangalloang sendiri masyoritas memiliki karakter khas daerah Desa Pangalloang yaitu dinamis, kreatif, sopan dan ramah tamah. Sebagian besar penduduknya berada pada usia muda yang merupakan usia produktif, sehingga kondisi demografi yang demikian menunjukkan bahwa potensi sumber daya manusia yang dimiliki Desa Pangalloang cukup memadai sebagai potensi dalam proses mengembangan ekonomi lokal di Desa Pangalloang.

\section{a. Bagaimana upaya yang dilakukan dalam pengembangan ekonomi lokal Perencanaan}

Pengembangan ekonomi lokal merupakan proses di mana pemerintah lokal dan organsisasi masyarakat terlibat untuk mendorong, merangsang, memelihara, aktivitas usaha untuk menciptakan lapangan pekerjaan (Blakely and Bradshaw, 1994). Di Desa pangalloang sendiri pengembangan ekonomi lokal telah dilakukan dengan melihat potensi-potensi yang ada untuk selanjutnya dikembangkan menjadi produk unggulan. Untuk melihat potensi-potensi yang menjadi unggulan

Di Desa pangalloang sendiri awal mula pengembangan ekonomi lokal memang berawal dari pemerintah. Pada saat itu pemerintah melihat bahwa banyak potensi-potensi yang ada di Di Desa pangalloang yang seharusnya dapat dikembangkan menjadi produk -produk lain agar memiliki nilai jual yang tinggi. Melihat potensi-potensi pertanian yang ada maka pemerintah Desa melakukan pengembangan ekonomi lokal di Desa tersebut dengan melihat potensi pertanian pada Desa,. Karena masyarakat masih bersifat tradisional dan kurang mengerti tentang pertanian modern, maka pemerintah memberikan pelatihan-pelatihan untuk meningkatkan wawasan para petani atas kerjsama yang dilakukan oleh Dinas pertanian selain itu pemerintah juga memberikan bantuan seperti alat produksi bagi masyarakat yang memiliki usaha kecil atas kerjasama Dinas sosial pemerintah daerah menunjang keberhasilan pengembangan ekonomi lokal ini.

PEL adalah usaha mengoptimalkan sumber daya lokal yang melibatkan pemerintah, dunia usaha, masyarakat lokal dan organisasi masyarakat madani untuk mengembangkan ekonomi pada suatu wilayah. Berdasarkan hasil wawancara dengan Bapak Asdar HC Manja mengatakan bahwa:

"Awalnya pemerintah melihat potensi-potensi pertanian yang ada di Desa pangalloang terlihat dengan banyaknya masyarakat yang mata pencahariannya sebagai petani karena keadaan tanah yang subur. Untuk meningkatkan pertanian tersebut maka pemerintah memberikan pelatihan-pelatihan pertanian terpadu (Model integrasi tanaman dan ternak) untuk lebih meningkatkan wawasan para petani."

Penerapan system terpadu sangat efektif dan efisien berupa peningkatan hasil produksi dan penurunan biaya produksi. Kegiatan terpadu antara pertanian dan peternakan ini sangat menunjang dalam menyediakan pupuk kandang dilahan pertanian. Dalam pengembangan ekonomi lokal Pemerintah Desa juga bekerja sama dengan dinas pertanian,dan juga antara pemerintah Desa dan dinas sosial. Dapat dilihat dari hasil wawancara dengan Bapak Ulla mengatakan bahwa:

"Setelah saya mengikuti pelatihan pertanian Terpadu yang dilaksanakan oleh pemerintah Desa yang bekerja sama dengan Dinas Pertanian, saya merasa terbantu dengan adanya pelatihan tersebut dengan mendapat banyak pengetahuan pertanian terpadu. saya mencoba mempratekkan pengetahuan yang di dapat dengan menggunakan pupuk kandang untuk lebih menyuburkan tanah. Dan benar bahwa setelah melakukannya hasil pertanian saya semakin meningkat dan juga biaya yang saya keluarkan menurun."

Pengembangan ekonomi lokal di Desa Pangalloang juga mengarah kepada pembangunan saluran irigasi. Dari hasil Wawancara kepala dusun bapak ambo di mengatakan bahwa:

"Sehubungan dengan banyaknya warga yang berprofesi sebagai petani maka Kepala Desa dusun menyarankan untuk membangun saluran irigasi agar para petani bisa melakukan panen padi 2-3 kali dalam setahun tapi sampai sekarang pembagunan saluran 
irigasi belum dapat di realisasikan oleh pemerintah Desa".Harapan yang kepala dusun ini untuk membantu masyrakat setempat dalam mengelolah lahan pertanian hingga bisa melakukan penen padi 2-3 kali dalam setahun"

Kepala Desa menegaskan bahwa Dana Desa yang telah diterima digunakan untuk kepentingan masyarakat yang paling utama yaitu perbaikan jalan dan pembangunan jembatan dengan anggaran sebesar Rp. 261.380.000 dan pembangunan Drainase sebesar Rp.336.313.000

Analisa Faktor Pendukung dalam Pengembangan Ekonomi Lokal di Desa Pangalloang Terdapat beberapa hal yang menjadi faktor pendukung dalam pengembangan ekonomi lokal ini diantaranya yaitu:

1. Tersedianya sumber daya alam yang melimpah. Pada Desa Pangalloang sendiri memiliki sumber daya alam yang melimpah khususnya dalam sumber daya pertanian. Banyak berbagai jenis tanaman dapat tumbuh subur di sana seperti padi, cengkeh, sayur-sayuran dan buah-buahan.

2. Keberadaan sumber daya manusia yang baik. Banyaknya jumlah penduduk di Desa Pangalloang membuat peluang pengembangan ekonomi lokal ini semakin besar karena banyak yang akan mengembangkan ekonomi lokal ini pada daerahnya masing-masing.

\section{Pembahasan}

Dalam pembahasan ini, akan dianalisis permasalahan yang terjadi berdasarkan hasil penelitian tentang faktor yang mendukung pengelolaan Dana Desa dalam pengembangan ekonomi lokal, Faktor-faktor yang mendukung pelaksanaan program Dana Desa dalam pengembangan ekonomi lokal, upaya yang dilakukan dalam pengembangan ekonomi lokal di Desa Pangalloang, Kec.Rilau Ale, Kab.Bulukumba.

\section{Faktor pendukung pengelolaan Dana Desa dalam pengembangan ekonomi lokal}

Dana Desa sebagaimana dimaksud dalam Pasal 5 Peraturan Pemerintah Republik Indonesia Nomor 60 Tahun 2014 Tentang Dana Desa Yang Bersumber Dari Anggaran Pendapatan Dan Belanja Negara ditransfer melalui APBD Kabupaten/Kota untuk selanjutnya ditransfer ke APBDesa dan digunakan untuk membiayai penyelenggaraan pemerintahan, pelaksanaan pembangunan, pembinaan kemasyarakatan, dan pemberdayaan masyarakat.

Pengelolaan keuangan Dana Desa merupakan bagian penting yang tidak dipisahkan dari pengelolaan keuangan Desa dalam APBDes. Seluruh kegiatan yang diDanai oleh Alokasi Dana Desa direncanakan, dilaksanakan dan dievaluasi secara terbuka dengan melibatkan seluruh unsur masyarakat Desa. Seluruh kegiatan harus dapat dipertanggungjawabkan secara administratif, teknis dan hukum.

Pengelolaan Keuangan Desa dipegang oleh Kepala Desa. Namun demikian dalam pelaksanaannya, kekuasaan tersebut sebagian dikuasakan kepada perangkat Desa sehingga pelaksanaan pengelolaan keuangan dilaksanakan secara bersama-sama oleh Kepala Desa dan Pelaksana Teknis Pengelolaan Keuangan Desa (PTPKD). PTPKD terdiri dari Sekretaris Desa, Kepala Seksi dan Bendahara Desa.

Kepala Desa sebagai Kepala Pemerintah Desa adalah Pemegang Kekuasaan Pengelolaan Keuangan Desa dan mewakili Pemerintah Desa dalam kepemilikan kekayaan Desa yang dipisahkan mempunyai kewenangan:

a. menetapkan kebijakan tentang pelaksanaan APB Desa;

b. menetapkan kebijakan tentang pengelolaan Barang Desa;

c. menetapkan Bendahara Desa;

d. menetapkan petugas yang melakukan pemungutan penerimaan Desa;

e. menetapkan petugas yang melakukan pengelolaan Barang Milik Desa:

f. mengesahkan RAB;

g. melakukan pemeriksaan kas sekurang-kurangnya 3 (tiga) bulan sekali dengan dibuatkan berita acara pemeriksaan kas;

h. menetapkan PTPKD berasal dari unsur Sekretaris Desa atau Kepala seksi;

i. menyetujui pengeluaran atas kegiatan yang ditetapkan dalam APB Desa; dan

Dana Desa Dalam Pengembangan Ekonomi Lokal (Studi di Desa Pangaloang, Kecamatan Rilau Ale, Kabupaten Bulukumba) | 37 
j. melakukan tindakan yang mengakibatkan pengeluaran atas beban APB Desa.

k. Kepala Desa dalam melaksanakan pengelolaan keuangan Desa, dibantu oleh PTPKD. Sekretaris Desa selaku Koordinator PTPKD membantu Kepala Desa dalam melaksanakan Pengelolaan Keuangan Desa, dengan tugas:

a. Menyusun dan melaksanakan kebijakan pengelolaan APB Desa;

b. Menyusun rancangan peraturan Desa mengenai APB Desa, perubahan APB Desa dan pertanggungjawaban pelaksanaan APB Desa;

c. Melakukan pengendalian terhadap pelaksanaan kegiatan yang telah ditetapkan dalam APB Desa;

d. Menyusun pelaporan dan pertanggungjawaban pelaksanaan APB Desa;

e. Melakukan verifikasi terhadap Rencana Anggaran Belanja (RAB), bukti-bukti penerimaan dan pengeluaran APB Desa (SPP).

Kepala Seksi merupakan salah satu unsur dari PTPKD yang bertindak sebagai pelaksana kegiatan sesuai dengan bidangnya. Sesuai pasal 64 PP Nomor 43 Tahun 2014 dinyatakan bahwa Desa paling banyak terdiri dari 3 (tiga) seksi. Kepala Seksi mempunyai tugas:

a. Menyusun RAB kegiatan yang menjadi tanggungjawabnya;

b. Melaksanakan kegiatan dan/atau bersama Lembaga Kemasyarakatan Desa yang telah ditetapkan di dalam APB Desa;

c. Melakukan tindakan pengeluaran yang menyebabkan atas beban anggaran belanja kegiatan;

d. Mengendalikan pelaksanaan dengan melakukan pencatatan dalam Buku Pembantu Kas Kegiatan;

e. Melaporkan perkembangan pelaksanaan kegiatan kepada Kepala Desa;

f. Mengajukan SPP dan melengkapinya dengan bukti-bukti pendukung atas beban pengeluaran pelaksanaan kegiatan.

Bendahara Desa merupakan salah satu unsur dari PTPKD yang dijabat oleh kepala/staf urusan keuangan dan memiliki tugas untuk membantu Sekretaris Desa. Penatausahaan yang dilakukan antara lain meliputi yaitu:

a. Menerima, menyimpan, menyetorkan/membayar, memungut dan menyetorkan PPH dan pajak lainnya;

b. Melakukan pencatatan setiap penerimaan dan pengeluaran serta melakukan tutup buku setiap akhir bulan secara tertib;

c. Mempertanggungjawabkan uang melalui laporan pertanggungjawaban.

\section{Faktor-faktor Pendukung pelaksanaan program Dana Desa dalam pengembangan ekonomi lokal.}

a. Kebijakan Pemerintah

Adanya Undang-Undang Nomor 32 Tahun 2004 tentang Pemerintah Daerah yang memiliki kewenangan membuat kebijakan tentang Desa dalam memberikan pelayanan, peningktan peran serta dan pemberdayaan masyarakat Desa yang ditujukan bagi kesejahteraan masyarakat. Sistem pengelolaan Alokasi Dana Desa yang dilakukan oleh Pemerintah Desa termasuk di dalamnya mekanisme penghimpunan dan pertanggung jawaban merujuk pada Undang-Undang Nomor 33 tahun 2004 tentang Perimbangan Keuangan antara Pemerintah Pusat dan Pemeintah Daerah. Dalam hal ini penDanaan mengikuti fungsi pemerintah yang menjadi kewajiban dan tanggung jawab masing-masing tingkat pemerintah.

Kemandirian Desa merupakan cita-cita ideal jangka panjang Untuk menuju cita-cita ideal Desa, : (a) mendekatkan perencanaan pembangunan ke masyarakat; (b) memperbaiki pelayanan publik dan pemerataan pembangunan; (c) menciptakan efisiensi pembiayaan pembangunan yang sesuai dengan kebutuhan lokal; (d) mendongkrak kesejahteraan perangkat Desa; (e) menggairahkan ekonomi lokal dan penghidupan masyarakat Desa; (f) memberikan kepercayaan, tanggungjawab dan tantangan bagi Desa untuk membangkitkan prakarsa dan potensi Desa; (g) menemba kapasitas Desa dalam mengelola pemerintahan dan pembangunan; (h) membuka arena pembelajaran yang sangat berharga bagi pemerintah Desa, Badan Perwakilan Desa dan masyarakat; dan (i) merangsang tumbuhnya partisipasi masyarakat lokal. 
Alokasi Dana Desa merupakan kebijakan pemerintah seiring dengan bergulirnya otonomi daerah, yaitu dimulai berlakunya Undang-Undang Nomor 22 Tahun 1999 yang kemudian direvisi dengan Undang-Undang Nomor 32 Tahun 2004. Saat Desa diserahi wewenang mengelola Alokasi Dana Desa yang bisa digunakan, Desa untuk menyelesaikan masalah mereka, Desa merasa diberi kepercayaan dan tantangan membangun Desanya secara partisipatif.

Kebershasilan ADD untuk pembangunan perdesaan memerlukan peningkatan kemampuan administrasi perangkat desa, tersedianya sistem sanksi yang tegas atas setiap pelanggaran dan peningkatan kepedulian masyarakat dalam pengawasan keuangan (Abidin, 2015).

b. Peran Masyarakat

Sesuai makna yang terangkum dalam pengertian Desa sebagai kesatuan masyarakat hukum yang berhak mengatur dan mengurus kepentingannya sendiri sendiri, maka peran dan keterlibatan masyarakat dalam penyelenggaraan pemerintahan dan pembangunan Desa menjadi keharusan. Karena, pada dasarnya Desa adalah organisasi milik masyarakat. Tata kelola Desa secara tegas juga menyaratkan hal itu, terlihat dari fungsi pokok Musyawarah Desa sebagai forum pembahasan tertinggi di Desa bagi Kepala Desa (Pemerintah Desa), BPD, dan unsurunsur masyarakat untuk membahas hal hal strategis bagi keberadaan dan kepentingan Desa.

Dengan demikian, peran dan keterlibatan masyarakat juga menjadi keharusan dalam Pengelolaan Keuangan Desa. Oleh sebab itu, setiap tahap kegiatan Pengelolaan Keuangan Desa harus memberikan memberikan ruang bagi peran dan keterlibatan masyarakat. Masyarakat dimaksud secara longgar dapat dipahami sebagai warga Desa setempat, 2 orang atau lebih, secara sendiri-sendiri maupun bersama, berperan dan terlibat secara positif dan memberikan sumbangsih dalam Pengelolaan Keuangan Desa. Namun bila hal itu dilakukan secara pribadi oleh orang seorang warga Desa, tentu akan cukup merepotkan. Oleh karena itu, peran dan keterlibatan dimaksud hendaknya dilakukan oleh para warga Desa secara terorganisasi melalui Lembaga Kemasyarakatan dan/atau Lembaga Masyarakat yang ada di Desa setempat.

Peran dan keterlibatan masyarakat menjadi faktor penting, karena:

a. Menumbuhkan rasa tanggungjawab masyarakat atas segala hal yang telah diputuskan dan dilaksanakan;

b. Menumbuhkan rasa memiliki, sehingga masyarakat sadar dan sanggup untuk memelihara dan mengembangkan hasil-hasil pembangunan.

c. Memberikan legitimasi/keabsahan atas segala yang telah diputuskan.

\section{Upaya yang dilakukan dalam pengembangan ekonomi lokal.}

Hasil Analisa Terhadap Regulasi Pendukung Pengembangan Ekonomi Lokal dengan adanya Undang-Undang No. 32 Tahun 2004 tentang Otonomi Daerah, maka membuka peluang pemerintah Desa Pangalloang untuk mengatur dan melakukan intervensi langsung dalam pengembangan ekonomi lokal didaerahnya. Hal ini dinilai sangat baik, karena pemerintah Desa Pangalloang mempunyai wewenang dalam membuat kebijakan pengembangan ekonomi daerah yang didasarkan pada pengembangan sektor-sektor unggulan yang memiliki nilai kompetitif dan berorientasi global di masing-masing wilayahnya. Konsep pengembangan ekonomi lokal merupakan konsep pembangunan yang didasarkan pada kapasitas lokal yang semakin berkembang. Prinsip utama dalam pengembangan ekonomi lokal adalah kemitraan. Adanya kerjasama pemerintah daerah, swasta dan masyarakat sangat menentukkan keberhasilan dan keberlanjutan program pengembangan ekonomi lokal dalam suatu wilayah.

Pengembangan ekonomi lokal dilaksanakan dengan melihat potensi-potensi yang ada di sektor pertanian terlebih dahulu. Dalam meningkatkan konsep pengembangan ekonomi lokal ini tentu saja tidak lepas dari peran pemerintah, dimana pemerintah memberikan pelatihanpelatihan, bantuan modaluntuk menunjang keberhasilan pengembangan ekonomi lokal. Selain itu peran dari masyarakat itu sendiri juga merupakan faktor penting dalam pengembangan ekonomi lokal di Desa Pangalloang. 
Peran Serta Masyarakat Dalam Mengembangkan Ekonomi Lokal di Desa Pangalloang sangat mempengaruhi dalam berjalannya proses pengembangan ekonomi lokal. Karena tanpa adanya peran dari masyarakat tentu saja pengembangan ekonomi lokal tidak akan dapat berjalan dengan baik.

\section{Conclusions}

Berdasarkan hasil penelitian dan pembahasan, maka dapat ditarik kesimpulkan sebagai

1. Faktor yang mendukung pengeloalaan Dana Desa dalam pengembangan ekonomi lokal di Desa Pangalloang adalah Kepala Desa namun dalam hal pelaksanaannya pengelolaan keuangan Desa di kuasakan kepada perangkat Desa diantaranya Sekretaris Desa, Pelaksana Teknis dan Bendahara.

2. Faktor yang mendukung pelaksanaan program Dana Desa dalam pengembangan ekonomi lokal di Desa Pangalloang yaitu adanya kebijakan dari pemerintah untuk melakukan kerja sama oleh pihak swata seperti dalam pembagunan jalan dan peran serta masyarakat setempat.

3. Upaya yang dilakukan dalam pengembangan ekonomi lokal di Desa Pangalloang yaitu adanya perencanaan yang dilakukan dan menghipung aspirasi masyarakt, dengan melihat potensi yang pelu di kembangkan untuk melakukan pengembangan ekonomi lokal.

\section{References}

Abidin, Muhammad Zainul. 2015. Tinjauan Atas Pelaksanaan Keuangan Desa Dalam Mendukung Kebijakan Dana Desa. Jurnal Ekonomi \& Kebijakan Publik, 6(1), 61-76.

Atmojo, Muhammad Eko., Fridayani, Helen Dian., Kasiwi, Aulia Nur., Pratama, Mardha Adhi. 2017. Efektivitas Dana Desa Untuk Pengembangan Potensi Ekonomi Berbasis Partisipasi Masyarakat Di Desa Bangunjiwo. Aristo Journal: (Social, Politic, Humaniora), Vol. 5 (1), 126-140.

Hariyanto, O. I. B. (2016). Destinasi Wisata Budaya Dan Religi Di Cirebon. Ecodemica, 4(2), 214-222.

Hermawan, Hary. 2016. Dampak Pengembangan Desa Wisata Nglanggeran Terhadap Ekonomi Masyarakat Lokal. Jurnal Pariwisata, Vol. Iii No. 2 Hal. 105-117

Iqbal, Muhammad., Anugrah, Iwan Setiajie. 2009. Rancang Bangun Sinergi Kebijakan Agropolitan Dan Pengembangan Ekonomi Lokal Menunjang Percepatan Pembangunan Wilayah. Analisis Kebijakan Pertanian. Vol. 7 (2)., Hal. 169-188.

Kartika, Ray Septianis. 2012. Partisipasi Masyarakat Dalam Mengelola Alokasi Dana Desa (Add) Di Desa Tegeswetan Dan Desa Jangkrikan Kecamatan Kepil Kabupaten Wonosobo. Jurnal Bina Praja, 4 (3), 179-188.

Mahfud . 2009. Analisis Dampak Alokasi Dana Desa Terhadap Pemberdayaan Masyarakat Dan Kelembagaan Desa. Jurnal Organisasi Dan Manajemen, 5(1). 10-22.

Soleh, Ahmad. 2017. Strategi Pengembangan Potensi Desa. Jurnal Sungkari. Vol. 5 (1), 32-52. 
Susanti, E.A., Hanafi, I., Adiono, R. 2013. Pengembangan Ekonomi Local Dalam Sector Pertanian (Studi Pada Kecamatan Pegelaran Kabupaten Malang). Jurnal Administrasi Public. Vol. 1 No. 4 Hal. 31-40.

Putra, Chandra Kusuma., Pratiwi, Ratih Nur., Suwondo. (2013). Pengelolaan Alokasi Dana Desa Dalam Pemberdayaan Masyarakat Desa (Studi Pada Desa Wonorejo Kecamatan Singosari Kabupaten Malang). Jurnal Administrasi Publik Vol. 1 No 6. Hal 1203-1212. 